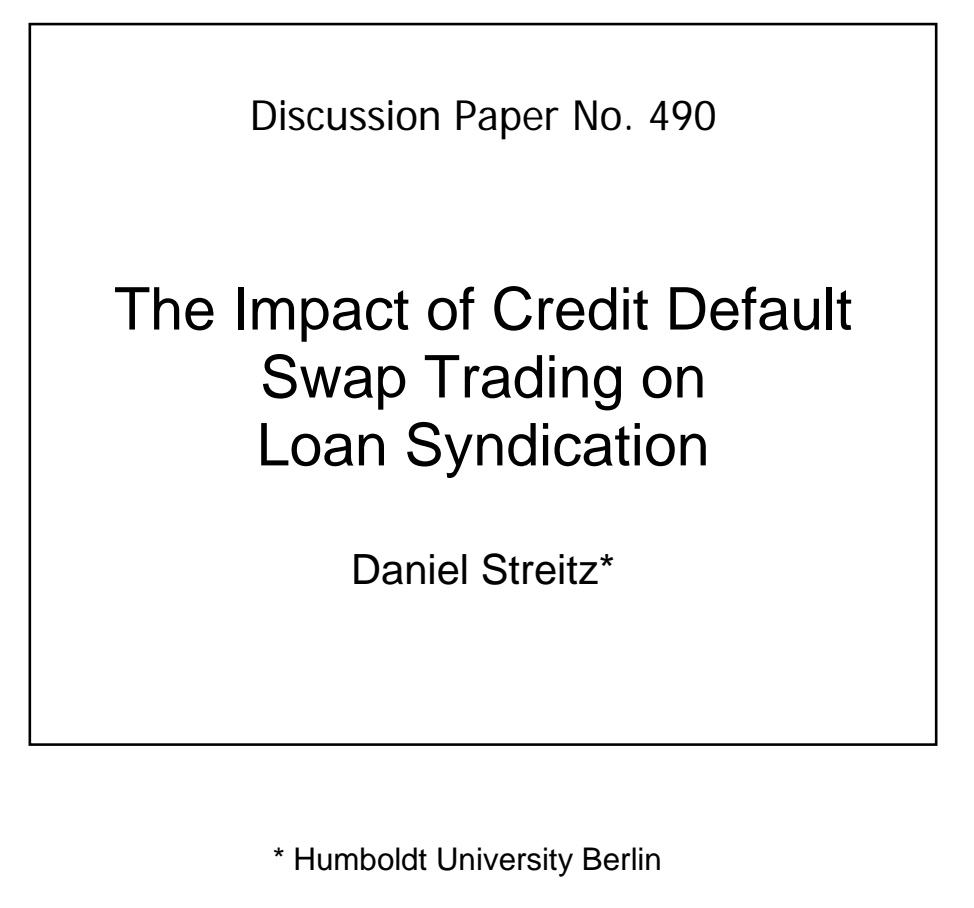

February 2, 2015

Financial support from the Deutsche Forschungsgemeinschaft through SFB/TR 15 is gratefully acknowledged. 


\title{
The Impact of Credit Default Swap Trading on
}

\author{
Loan Syndication
}

Daniel Streitz*

February 2, 2015

\begin{abstract}
We analyze the impact of CDS trading on bank syndication activity. Theoretically, the effect of CDS trading is ambiguous: on the one hand, CDS can improve risksharing and hence be a more flexible risk management tool than loan syndication; on the other hand, CDS trading can reduce bank monitoring incentives. We document that banks are less likely to syndicate loans and retain a larger loan fraction once CDS are actively traded on the borrower's debt. We then discern the risk management and the moral hazard channel. We find no evidence that the reduced likelihood to syndicate loans is a result of increased moral hazard problems.
\end{abstract}

Keywords: Loan Sales, Credit Default Swaps, Syndicate Structure, Syndicated Loans

JEL-Classification: G21, G32

${ }^{*}$ Daniel Streitz is from the Institute of Corporate Finance at Humboldt University Berlin. The author would like to thank Tim Adam, Tobias Berg, Valentin Burg, Sudipto Dasgupta, Hermann Elendner, Xavier Giroud, Laurenz Klipper, Augustin Landier, Christian Laux, Gustavo Manso, Martin Oehmke, Steven Ongena (the editor), Gordon Phillips, Tobias Scheinert, Sascha Steffen, Alex Stomper, Gunter Strobl, and an anonymous referee for helpful comments and suggestions. Some of the work on this paper was completed while the author was visiting USC Marshall School of Business. The author gratefully acknowledges financial support from the Deutsche Forschungsgemeinschaft through SFB 649 "Economic Risk" and SFB-TR15 "Governance and the Efficiency of Economic Systems". Send correspondence to Daniel Streitz, Institute of Corporate Finance, Dorotheenstrasse 1, 10099 Berlin, Germany; E-mail: daniel.streitz@wiwi.hu-berlin.de. 


\title{
The Impact of Credit Default Swap Trading on
}

\author{
Loan Syndication
}

February 2, 2015

\begin{abstract}
We analyze the impact of CDS trading on bank syndication activity. Theoretically, the effect of CDS trading is ambiguous: on the one hand, CDS can improve risksharing and hence be a more flexible risk management tool than loan syndication; on the other hand, CDS trading can reduce bank monitoring incentives. We document that banks are less likely to syndicate loans and retain a larger loan fraction once CDS are actively traded on the borrower's debt. We then discern the risk management and the moral hazard channel. We find no evidence that the reduced likelihood to syndicate loans is a result of increased moral hazard problems.
\end{abstract}

Keywords: Loan Sales, Credit Default Swaps, Syndicate Structure, Syndicated Loans JEL-Classification: G21, G32

\footnotetext{
${ }^{*}$ A version of this paper was previously circulated under the title "Loan Sales versus Credit Default Swaps - The Promise and Perils of Financial Innovation".
} 


\section{Introduction}

Despite the growing importance of credit derivatives in recent years, the impacts of this financial innovation on the nature and operation of credit markets are not yet fully understood. The enhanced risk-sharing via credit default swaps (CDS) can alleviate credit supply frictions (Saretto and Tookes (2013); Shan et al. (2014)). However, a necessary condition for any positive effect of CDS trading is that creditors actively use CDS to manage credit risk. Empirical research on how and to what extent banks use CDS is scarce.

One important determinant of the effects of CDS on credit markets is the interplay with banks' existing risk management tools, such as loan syndication. A bank can limit the exposure to a borrower in order to comply with regulatory capital requirements and diversify the loan portfolio by syndicating, i.e., partially selling, loans (Dennis and Mullineaux (2000)). While both CDS and partial loan sales can be used to lay off credit risk, tailor-made CDS are more flexible than loan sales (Duffee and Zhou (2001)). Hence, banks may rely less on loan syndication once CDS become available.

However, there is a potential cost to the availability of CDS. Loan sales and CDS differ in one key aspect: loan sales transfer both credit risk and control rights to the counterparty, while CDS only transfer the credit risk. Hence, CDS trading could have a detrimental effect on bank monitoring incentives because although the credit risk is transferred to the counterparty, the control rights remain with the bank (Parlour and Winton (2013)). If the lead arranger in a syndicated loan can lay off credit risk anonymously via CDS, potential participants may be less willing to invest, as they might fear that the lead bank will no longer monitor the borrower. Hence, syndication 
may become more difficult/costly and originating banks would be forced to retain larger shares in their loans. Overall, while the theoretical effect of CDS trading on syndication is unambiguous - banks rely less on syndication once credit protection via CDS is available - different economic mechanisms can lead to this conjecture.

The aim of this paper is to empirically analyze the impact of CDS trading on loan syndication. Further, we explicitly differentiate risk management from moral hazard effects. We document that banks are $3 \%$ less likely to syndicate a loan once credit protection via CDS is available. This is economically relevant given that only about $10 \%$ of the loans in our sample are single lender loans. On average, lead banks also retain $5.5 \%$ more of a loan after CDS introduction. These effects are particularly strong if the loan is large and if the bank is more likely to use CDS for hedging purposes. These results document a significant impact of CDS trading on primary loan markets.

Next, we differentiate the risk management from the moral hazard effect. Parlour and Winton (2013) show theoretically that moral hazard problems arising from CDS trading are less severe if the lender's reputation is high. Our results, however, indicate that the effect of CDS trading on the decision to syndicate a loan is increasing in lead arranger reputation. This means that especially large reputable banks are less likely to sell a loan after hedging via CDS is possible. This is inconsistent with moral hazard concerns but consistent with the notion that larger, more reputable banks are more likely to be active in the CDS market and also use CDS for hedging purposes (Hirtle (2009)). We then analyze loan outcomes that likely are correlated with the monitoring service provided by banks. In particular, we test whether firms are more likely to violate covenants after CDS are traded on the firms' debt. Our results indicate that this is not the case. If anything, firms are less likely to violate covenants after CDS 
inception. Finally, we analyze whether effect of CDS trading on syndication propensity is stronger for borrowers who require intensive monitoring, e.g., riskier, more opaque firms. We document that the effect is similar across borrowers.

Overall, our results indicate that an increase in moral hazard caused by CDS introduction is not a major concern in the syndicated loan market. We find that the effect of CDS trading on syndication propensity is stronger for (i) larger, more reputable banks, (ii) banks that are more likely to use CDS for hedging purposes, and (iii) larger loans. These findings suggest that banks actively use CDS to manage credit risk and substitute partial loan sales with CDS once they become available.

CDS trading and the timing of CDS inception are clearly endogenous, hence this problem needs to be addressed in order to make causal inferences about the effect of CDS trading on syndication. We address these concerns by constructing a model to predict CDS trading and further use this model to run an instrumental variable estimation. We follow Saretto and Tookes (2013) and Subrahmanyam et al. (2014) and use banks' foreign exchange derivative holdings as an instrument for CDS trading. ${ }^{1}$ Our results are robust to potential endogeneity concerns.

We contribute to the literature by providing novel evidence that banks actively use CDS as a risk management tool, relying less on other risk sharing mechanisms. Understanding the trade-off between different risk management tools is important to better comprehend the conditions under which CDS trading reduces credit supply

\footnotetext{
1 Minton et al. (2008) show that banks, which use foreign exchange derivatives are more likely to be net buyers of CDS, i.e., are more prone to use derivatives in general. Therefore, foreign exchange derivatives holdings are likely to be correlated with investor demand for credit protection via CDS. As foreign exchange hedges are macro hedges, it is unlikely that this variable is directly related to the decision to syndicate a loan.
} 
frictions. If CDS trading replaces existing risk management tools, it is unlikely to have a strong impact on credit supply by banks and on loan contract terms. This is consistent with existing studies, which find mixed effects of CDS trading on credit markets (Hirtle (2009); Ashcraft and Santos (2009); Saretto and Tookes (2013); Shan et al. (2014)). ${ }^{2}$

The rest of the paper is organized as follows. Section 2 discusses the theoretical background and derives empirical hypotheses. Section 3 describes our sample selection process. The main empirical analysis, demonstrating a link between CDS trading and bank syndication activity, is presented in Section 4 . Section 5 differentiates the moral hazard from the risk management channel. Section 6 concludes.

\section{Theoretical Framework}

In a Modigliani-Miller world, bank risk management does not increase firm value as shareholders can manage risks more efficiently by holding a well-diversified portfolio. However, market frictions such as moral hazard and adverse selection problems lead banks to acquire borrower specific private information that can make bank loans illiquid and loan sales difficult. Further, if loans incorporate private information, bank failures are costly as loans cannot be liquidated without deadweight loss (Goderis et al. (2007); Cebenoyan and Strahan (2004)). Finally, banks are required by regulation to implement risk management tools and hold equity capital to back-up risky assets. Overall,

2 Several studies analyze the effect of CDS trading on the bond market. For example, Das et al. (2014) find no evidence for an increase in bond market liquidity or a reduction in pricing errors. Chava et al. (2012) show that credit ratings become less important when a market price for the risk of a company can be observed. 
banks have strong incentives to actively manage the risk of their loan portfolio. ${ }^{3}$

Banks can manage credit risk through syndication. In a syndicated loan, the lead bank negotiates the deal with the borrower and then decides upon which fraction of the loan to sell to other participating lenders. Thereby, the bank can limit the size of any single loan to comply with regulatory capital requirements and diversify their loan portfolio by taking smaller shares in multiple syndicated loans (Dennis and Mullineaux $(2000)) \cdot{ }^{4}$

Recently more and more firms that borrow from banks have actively traded CDS on their debt. The CDS market is an over-the-counter derivative market where default protection for corporate bonds and loans can be bought. Banks that have access to credit derivatives therefore have an alternative tool to manage the risk associated with a loan. The question that arises is whether and how a market in which loan syndication, i.e., partial loan sales, exist is affected by the availability of CDS?

Duffee and Zhou (2001) show theoretically that CDS can be a more flexible tool to manage credit risk compared to loan sales if the banks informational advantage is nonconstant over the life of the loan. The lead bank is considered an "informed lender" who knows more about the true credit quality of the borrower than the potential participants (Diamond (1984)). The arising adverse selection problems make loan sales costly. Gorton and Pennachi (1995) show that banks will only sell loans if the banks' internal funding costs are sufficiently high and/or the cost of funding loans via loan sales is sufficiently small. If the banks informational advantage varies over the life of a loan as in Duffee and Zhou (2001), it is therefore optimal for the bank to lay off a 3 See also Froot and Stein (1998) and Froot et al. (1993).

4 Consistent with the risk sharing motive for loan syndication, Dennis and Mullineaux (2000) find that banks are more likely to syndicate larger loans and loans with longer maturities. 
larger (smaller) part of the credit risk when the information asymmetry is low (high). Thereby, the bank can minimize the costs of adverse selection. Duffee and Zhou (2001) show that tailor-made CDS are a flexible tool to temporarily lay off credit risk. Loan sales, on the other hand, are less flexible as the loan is no longer on the bank's balance sheet.

Hypothesis 1: Risk management via CDS is more flexible than risk management via syndication. Therefore, banks are less likely to syndicate loans and retain larger loan shares once credit derivatives are actively traded on a borrower's debt.

Sufi (2007) argues, building on the models of Holmstrom (1979), Holmstrom and Tirole (1997), and Gorton and Pennachi (1995), that moral hazard problems exist in syndicated loans. The "informed" lead arranger is able to monitor and learn about the borrower through unobservable and costly effort. Participants, on the other hand, are "uninformed lenders" who rely on the monitoring effort by the lead arranger. The lower the share of a loan that is retained by the lead arranger, the lower are the incentives to actively monitor the borrower. As potential participants are aware of this problem, they are only willing to invest if the lead arranger retains a large enough fraction of the loan to credibly commit to monitor the borrower. As shown by Parlour and Winton (2013), retaining a larger share of the loan is no longer a credible signal by the bank if CDS are available. The lead arranger can lay off credit risk anonymously via CDS, which effectively reduces the incentive to monitor. Without a credible signal by the lead arranger, potential investors are less willing to participate in a syndicated loan. Hence, syndication becomes less likely and the lead arranger has to retain a larger share of the loan. 
Hypothesis 2: A commitment to monitor the borrower is less credible if laying off credit risk via CDS is possible, hence investors are less willing to participate in a syndicated loan. Therefore, banks are less likely to syndicate loans and retain larger loan shares once credit derivatives are actively traded on a borrower's debt.

Note that both Hypothesis 1 and 2 predict that the lead lender will retain a larger fraction in syndicated loans. However, the reasons differ: Hypothesis 1 predicts that the lender will (partially) substitute syndication via the purchase of CDS. Hypothesis 2 predicts that syndication becomes more difficult because the lender can no longer credibly commit to monitor the borrower if CDS are available. Which effect prevails is an empirical question that will be addressed in the following analysis.

\section{Data}

\subsection{Sample Selection and Main Variables}

We use all USD denominated CDS spreads for all maturities obtained from Bloomberg and the CMA database to identify firms that have actively traded CDS on their debt. We manually match all reference entity names with the borrower names in the LPC Dealscan database, which contains detailed information on corporate loan contracts. We discard financial firms (SIC codes 6000-6999) and restrict the sample to the period from 2000 to $2010 .^{5}$ We further exclude all loans by firms that have actively traded CDS on their debt at any time during the sample period but only issue loans before

5 Loans issued prior to 2000 are excluded as the vast majority of CDS introduction dates are after 2000. However, not imposing this restriction and using all loans originated between 1990 and 2010 yields qualitatively similar results. 
or after the CDS introduction. Following Sufi (2007), we classify a lender as a lead arranger if the variable called "Lead Arranger Credit" (provided by Dealscan) takes on the value "Yes" or if the lender is the only lender specified in the loan contract. The final sample is unique at the facility-lead arrangers level, i.e., there are multiple observations per loan facility in case of multiple lead arrangers. This sample structure allows us to control for borrower $\mathrm{x}$ lead arranger interaction fixed effects throughout the empirical analyses, i.e., we control for any unobservable borrower and bank characteristics that are time-invariant. Finally, we merge the loan data to Compustat to obtain financial information on the borrowers. ${ }^{6}$

We use Lead Share (\%) and Sole Lender (0/1) as our main dependent variables. Lead Share (\%) is the percent of the total loan held by the lead bank. Sole Lender (0/1) is a dummy variable, which equals one for single lender loans and zero for syndicated loans. These variables are a direct outcome of the decision to partially sell a loan on the primary market. The primary independent variable of interest is CDS Trading (0/1), a dummy, which equals one if a firm has actively traded CDS on its debt at the time of loan origination, and zero otherwise. This variable captures the marginal impact of CDS introduction on primary loan market allocation.

\subsection{Descriptives}

Table 1 presents descriptive statistics for the final panel, distinguishing between firms that have actively traded CDS on their debt at any point in time during the sample period and firms that never have actively traded CDS during the sample period. The

\footnotetext{
6 We use Michael Robert's Dealscan-Compustat Linking Database to merge Dealscan with Compustat (see Chava and Roberts (2008) for details).
} 
sample comprises 21,122 facility-lead arranger combinations, 14,379 facilities, and 3,202 distinct borrowers. Thereof, 327 companies have actively traded CDS at some point in time during the sample period.

[Table 1 here]

Panel A reports descriptives for the CDS trading indicator. $51 \%$ of the loans by CDS firms are issued after CDS inception. Panel B reports descriptives for loan characteristics. The mean share of the loan retained by the lead arranger is $62 \%$ for non-CDS firms and $33 \%$ for CDS firms. ${ }^{7}$ The loan is not syndicated in $16 \% / 2 \%$ of cases for non-CDS/CDS firms. Unconditionally, differences in the lead share and the fraction of syndicated loans between CDS and non-CDS firms are unsurprising. Loans to CDS firms are significantly larger than loans to non-CDS firms: the mean/median loan amount is $\$ 240 / \$ 125$ million for non-CDS firms and $\$ 1,140 / \$ 700$ million for CDS firms. Further, CDS firms are significantly larger than non-CDS firms: the mean/median book value of assets is $\$ 17,700 / \$ 10,241$ million for CDS firms and $\$ 2,070 / \$ 779$ million for non-CDS firms (Panel C). In general, banks are more likely to syndicate larger loans and loans by larger borrowers (Dennis and Mullineaux (2000)), i.e., size differences likely explain the difference in the average lead share between CDS and non-CDS firms. We explicitly control for any differences between CDS and non-CDS firm in the multivariate analyses.

$\overline{7}$ Note that, the number of observations is lower for the variable Lead Share (\%), as the individual shares retained by the lenders are not reported for all loans included in the Dealscan database. However, there does not seem to be any systematic bias, i.e., loans with non-missing lead share are similar to other loans in terms of observable characteristics (see also Ivashina (2009)). Further, the fraction of loans with information on the lead share is similar for CDS and non-CDS firms, and for CDS firms similar before versus after CDS are traded on the borrowers' debt. 


\section{CDS Trading, Syndication Propensity, and Lead Share}

\subsection{Baseline Specification}

We start by establishing a general link between CDS trading and loan syndication. Figure 1 shows the average (median) loan share retained by the lead bank before and after CDS are actively traded on the borrowers' debt. Further reported is a control group. We build loan pairs via propensity score matching, i.e., for each loan by a borrower who has actively traded CDS on the debt at some point during the sample period we include a similar loan by a similar borrower who never has CDS traded on the debt. We match based on the observable loan and borrower characteristics reported in Table 1.8

[Figure 1 here]

The share retained by the lead arranger strongly increases from $24 \%$ to $28 \%$ after CDS are actively traded on a borrower's debt, indicating that there is indeed a structural break. The average lead share does not change significantly around the CDS introduction date for the control group. Figure 1 further reports medians. The figure suggests that the median share already increases before the CDS introduction. However, the proxy for the CDS introduction date is noisy and the univariate comparison can of course only serve as a first indication that CDS trading affects loan syndication. Other firm characteristics may have changed at the CDS introduction date and firms with actively traded CDS may differ from firms, which never have actively traded CDS during our sample period.

\footnotetext{
8 See Appendix B for matched sample summary statistics.
} 
We follow Ashcraft and Santos (2009) and Subrahmanyam et al. (2014) and address these issues by comparing firms before and after CDS are actively traded on the firms' debt with firms that never have actively traded CDS at any point in time during the sample period, using the following regression framework:

$$
\text { Syndication }_{i j t}=\alpha_{i j}+\alpha_{t}+\beta * C D S \text { Trading }(0 / 1)_{i t}+\gamma * X_{i t-1}+\delta * Y_{i j t}+\epsilon_{i j t} .
$$

Syndication indicates whether (or what fraction of) a loan $i$ is sold on the primary loan market by bank $j$ at time $t$. As discussed earlier, we construct two different specifications for this variable: (i) Sole Lender (0/1) indicates whether the loan is syndicated, i.e., partially sold on the primary market. (ii) Lead Share (\%) indicates the fraction of a loan retained by the lead arranger. CDS Trading (0/1) is a dummy variable, which equals one if a firm has active CDS trading at the time of the loan origination date, and zero otherwise. $X$ is a set of borrower characteristics and $Y$ a set of loan characteristics. ${ }^{9}$ We use firm size, measured by the log of total assets, the market-to-book ratio of assets, leverage, tangibility, profitability, the current ratio, the interest coverage ratio, the log of the facility amount, the deal maturity, the log of the number of financial covenants, and indicator variables for secured facilities and loans that include performance-pricing provisions as control variables. All variables are defined in more detail in the Appendix. We further include borrower $\mathrm{x}$ lead arranger interaction fixed effects $\left(\alpha_{i j}\right)$, i.e., we compare loans that the same borrower obtains from the same bank before versus after CDS are actively traded on the borrower's debt. We thereby control for any unobservable borrower and bank characteristics that

\footnotetext{
9 As common in the literature, we obtain borrower information from the last available fiscal year before the loan issue, i.e., at time $t-1$.
} 
are time-invariant. Further included are loan purpose and loan type indicators, time fixed effects, and dummy variables for each rating notch.

[Table 2 here]

The results reported in Table 2 provide evidence that banks are about $3 \%$ less likely to syndicate a loan once credit protection via CDS is available. This effect is economically relevant given that about $11 \%$ of the loans in the sample are single lender loans. Further, the share retained by the lead arranger increases by $5.5 \%$. Again, this effect is economically important as compared to the median value of $55 \%$, this change implies an increase in magnitude of about $10 \% .{ }^{10}$

Turning to the control variables, we find similar effects as Sufi (2007). The lead arranger retains a lower share of the loan if the borrower is larger, if the loan is larger, and if the maturity is longer. This evidence is consistent with the notion that larger firms are less opaque, therefore moral hazard and adverse selection problems are lower. Hence, the lead arranger can sell a larger fraction of the loan.

\footnotetext{
${ }^{10}$ One potential concern is that an increasing number of loans are traded in the secondary market. It could be that the availability of credit protection via CDS also increases the likelihood of secondary market trading. The lead arranger may initially agree to retain a larger fraction of the loan but immediately sell the loan after the origination. Unfortunately, Dealscan only provides loan information as of origination so one cannot track the syndicate composition over time. However, Ivashina and Sun (2011) show (using a hand collected sample of loan amendments) that lead arrangers almost never sell their stakes in the loan. We additionally address this issue by excluding all companies from the sample that issue loans, which are traded on the secondary market. We classify traded loans as loans that have a Loan Identification Number (LIN). The LIN is the main identifier in secondary loan market databases. For example, Drucker and Puri (2009) use the LIN to merge Dealscan with the Loan Syndications and Trading Association (LSTA) Mark-to-Market Pricing database. Our results remain unaffected.
} 


\subsection{Endogeneity}

One potential concern is that the selection of firms for CDS trading and the timing of CDS inception may be endogenous. Unobserved differences between CDS firms and non-CDS firms could influence both CDS inception and the decision to syndicate a loan. We follow Ashcraft and Santos (2009), Subrahmanyam et al. (2014), and Saretto and Tookes (2013) in that we address this issue by constructing a model to predict CDS trading for individual firms. As in Subrahmanyam et al. (2014) and Saretto and Tookes (2013), we use Lender FX Usage as an instrument for CDS Trading (0/1). Lender FX Usage is constructed at the firm-level for each year and is defined as the average amount of foreign exchange derivatives held by all the lead arrangers that lent money to the company in the previous five years as a fraction of the total assets of the lead arrangers. ${ }^{11}$ Minton et al. (2008) show that banks, which use foreign exchange derivatives are more likely to be net buyers of CDS, hence Lender FX Usage is correlated with investors' demand for CDS. As foreign exchange hedges are macro hedges, it is unlikely that this variable is directly related to the loan (and borrower) specific syndicate structure.

The economic intuition for using Lender FX Usage as an instrument for CDS Trading is that market participants who are overall more "derivative-affine" also have a higher demand for credit protection via CDS. Ideally one would like to use both bond and loan market information to determine investors' demand for CDS. However, as argued by Saretto and Tookes (2013) the hedging activity of firms' lead banks is expected to impact both the loan and bond components of firm's debt. Lead lenders

\footnotetext{
${ }^{11}$ As in Saretto and Tookes (2013) we use the foreign exchange derivatives used for hedging (not trading) purposes.
} 
are also likely to underwrite and hold firms' bonds. Yasuda (2005) shows that lead arrangers of a firm are also likely to be chosen as the bond underwriters. Goldstein and Hotchkiss (2007) find that lead underwriters also tend to hold significant fractions of the bonds.

[Table 3 here]

We use this model to predict CDS trading for each company in each year to employ an instrumental variable estimation. Thereby, the probability of CDS trading as predicted in the first stage is used as an instrument for CDS trading in the second stage. Table 3 reports the results of the instrumental variable estimation. Column 1 reports the model that is used to predict CDS trading. These results are similar to Subrahmanyam et al. (2014) and Saretto and Tookes (2013). Lender FX Usage is significantly positively related to $C D S$ Trading (0/1) confirming the validity of the inclusion restriction. The second stage results show that, the effect of CDS trading on Lead Share (\%) and Sole Lender (0/1) remains highly significant after addressing the endogeneity of CDS inception. Note that we lose observations compared to the baseline specification (Table 2), as FX derivative holdings are not available for all lead arrangers (e.g., foreign banks and nonbank lenders).

\subsection{Does the Effect of CDS Trading on Loan Syndication Vary with Bank CDS Holdings, Loan Size, and CDS Liquidity?}

Our evidence so far suggests that CDS trading has a significant impact on loan syndication. This evidence, however, is indirect in nature. Ideally one would like to have bank-level data on individual CDS holdings, i.e., detailed CDS holdings including the 
respective reference entities, which would allow for a clearer identification of the effect. Unfortunately, such data is not available. Banks are only obligated to disclose CDS holdings in an aggregated form and only since 2006. Nevertheless, this information allows for the classification of banks into CDS users and CDS nonusers. We construct a dummy variable, CDS Bank (0/1), which equals one if a lead lender ever reports a positive notional CDS amount (purchased protection) in the sample period, and zero otherwise. ${ }^{12}$ Further, we use Bank CDS Holdings, i.e., the notional CDS amount (\$million) that the lead lender reports in the quarter prior to the loan issue. While $C D S$ Bank (0/1) is a bank-fixed effect and therefore defined over the entire sample period, Bank CDS Holdings is only available from 2006 onwards. Using these two proxies we test if the effect of CDS trading on syndication propensity varies with bank CDS activity. Note that similar to the IV estimation (cf. Section 4.2) we lose observations compared to the baseline specification, as CDS holdings are not available for all lead arrangers. The results are reported in Table 4, Panel A.

[Table 4 here]

These results show that the effect of CDS trading on syndication propensity is particularly strong if the lead arranger is a CDS user or if the lead arranger reports high CDS holdings in the quarter prior to the loan issue. While these results provide further evidence that there is a direct effect of CDS trading on primary loan market allocation, the results are consistent with both Hypothesis 1 and 2. Banks may be

\footnotetext{
12 One drawback of this measure is that it uses information from the 2006 to 2010 period to classify banks over the 2000 to 2010 period as banks are obligated to disclose CDS holdings only from 2006 on. However, there is little time-variation in CDS usage on the bank-level in the 2006 to 2010 period, i.e., banks either always or never report positive CDS amounts. This justifies treating CDS usage as a bank-fixed effect.
} 
less likely to participate in a loan if they perceive the likelihood that the lead arranger hedges the default risk via CDS as high. Alternatively, banks that overall use more CDS may rely less on syndication. Hence, the results support the conjecture that CDS are a flexible risk management tool. We differentiate the moral hazard from the risk management effect in Section 5.

Saretto and Tookes (2013) document that firms with CDS traded on their debt maintain higher leverage ratios. Shan et al. (2014) provide evidence that firms with actively traded CDS on their debt obtain larger loans than non-CDS firms. If this is the case, the effect of CDS trading on primary loan market allocation may be even more prominent than documented so far. We therefore explicitly test if the effect of CDS trading on syndication propensity varies with loan size. The results are reported in Table 4, Panel B. They indicate that the effect of CDS trading on syndication propensity increases in loan size. Banks are in particular more likely to fully retain larger loans on their balance sheet once protection via CDS is available. This is a first indication that banks use CDS as risk management tools, as any risk management effect should be particularly strong for economically relevant loans. The effect, however, is only borderline significant.

Duffee and Zhou (2001) show theoretically that CDS can replace loan sales as CDS are a flexible way to temporarily lay off credit risk. However, the flexibility of CDS is likely determined by the liquidity in the CDS market. If the CDS that are traded on the borrowers' debt are illiquid, CDS trading is unlikely to have an effect on syndication propensity. We address this issue and use the borrowers' CDS bid-ask spread in the month before the loan origination as a proxy for the liquidity. We divide CDS Trading (0/1) intro three subsets: CDS Trading (0/1)* Low Liquidity (0/1), CDS 
Trading (0/1)*Medium Liquidity (0/1), and CDS Trading (0/1)*High Liquidity (0/1). Low, medium, and high liquidity are indicator variables for three CDS bid-ask spreads quantiles. The results reported in Table 4, Panel C, show that the effect of CDS trading on syndication is increasing in CDS liquidity.

\section{Risk Management versus Moral Hazard}

The evidence so far is consistent with both Hypothesis 1 and 2. Lead arrangers may be less likely to syndicate a loan because CDS are a more flexible risk management tool. Alternatively, lead arrangers may be less likely to syndicate a loan because investors are less willing to participate if the lender can no longer credibly commit to monitor the borrower. In this section, we differentiate the risk management from the moral hazard channel. In the ideal experimental environment, bank monitoring would be observable and CDS trading would be random. That is, it would be revealed after the loan contract is finalized whether the bank is able to hedge credit risk via CDS or not. If the assignment is random and if loan contract terms cannot be changed after the contract is finalized, the effect of CDS trading on bank monitoring would be causal.

Unfortunately, bank monitoring is not observable, hence we have to rely on indirect tests. In particular, we analyze whether the effect of CDS trading on syndication varies across borrowers and banks. Moral hazard problems are especially severe if the borrower requires extensive monitoring, or if the bank reputation is low. Further, we analyze whether CDS trading has a direct effect on loan outcomes that are correlated with monitoring services provided by banks, i.e., covenant violations.

In our empirical setting CDS trading is not random. In particular, as documented 
in Section 4., CDS trading has a direct impact on syndication propensity and the loan share retained by the lead arranger, which in turn has an effect on bank monitoring. This is particularly problematic when we analyze loan outcomes, i.e., covenant violations following loan issues. As before, we control for bank and firm fixed effects to control for unobservable time-invariant effects. Further, we perform the analysis of covenant violations both at the loan-level and at the firm-level. First, we analyze whether firms are in general more likely to violate loan covenants after CDS are actively traded on the firm's debt. Second, we analyze whether firms are more likely to violate a covenant in the $k$ quarters after obtaining a loan if the lender can hedge the credit risk via CDS. In particular, we compare loans by the same firm before versus after CDS are actively traded on the firm's debt controlling for the lead share. Note that due to data limitations this analysis is still indirect and we cannot control for unobservable time-variant effects such as post-issue changes in loan contract terms and lead share.

\subsection{Cross-Borrower Variation}

If the moral hazard effect is the dominant one, then this problem should be especially severe for borrowers that require extensive monitoring. Therefore, we analyze if the effect of CDS trading on syndication propensity is especially pronounced for more risky borrowers, and more opaque borrowers. We use a dummy variable, which equals one if the borrower has a sub-investment grade rating at the time of the loan origination, and zero otherwise as a proxy for borrower risk. We further use the borrowers' distance-todefault and Altman Z-Score. We use the number of analysts covering the firm and the fraction of tangible to total assets as proxies for firm opaqueness. Firms with higher 
analyst coverage and a larger fraction of fixed assets are typically assumed to be less opaque. Results are reported in Table 5.

[Table 5 here]

The results show that the effect of CDS trading on syndication propensity does not differ between borrowers with different required monitoring intensities, which is unsupportive of Hypothesis 2. ${ }^{13}$

\subsection{Bank Reputation}

As shown theoretically by Parlour and Winton (2013), moral hazard problems arising from CDS trading are less severe if lender reputation is high. Therefore, the effect of CDS trading on syndication should be particularly strong for less reputable firms if moral hazard is a significant concern. Following Sufi (2007), we measure lead arranger reputation, Bank Reputation, by the market share (by amount) of the lead arranger in the year prior to the loan in question. We further follow Ross (2010) and create a dummy variable, Big-3 Bank (0/1), which equals one if Citibank, JP Morgan Chase, or Bank of America are the lead arranger, and zero otherwise. Ross (2010) provides evidence that these three large banks control the majority of the US syndicated loan market and have a particularly high reputation for screening and monitoring borrowers. In addition, we extend this proxy to comprise the ten most active banks in the US syndicated loan market (Big-10 Bank (0/1)).

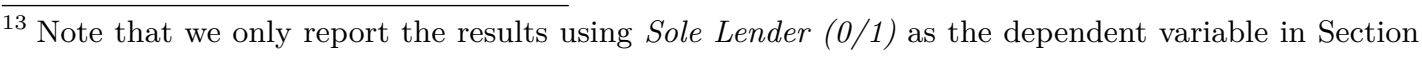
5.1 and 5.2 to save space. The results using Lead Share (\%) are virtually identical and available upon request.
} 
[Table 6 here]

Results reported in Table 6 show that the effect of CDS trading on syndication propensity does not vary significantly across banks with different reputations. If anything, the results suggest that the effect is stronger for more reputable banks. This is consistent with a risk management effect: larger, more reputable banks are more likely to actively use CDS (see Hirtle (2009) and Section 4.3).

\subsection{Loan Outcomes}

Finally, we examine variables that are likely to be affected by the monitoring service provided by banks. In particular, we analyze loan covenant violations. ${ }^{14}$

[Table 7 here]

The results reported in Table 7, column 1, show that firms are in general significantly less likely to violate a financial covenant once CDS are available. This evidence is again unsupportive of Hypothesis 2 but consistent with the notion that CDS are traded on rated, financially sound firms where moral hazard problems are unlikely. Also the loan-level analysis, Table 7, columns 2-3, indicates that firms are not more likely to violate covenants following loan issues before versus after CDS are actively traded on the firms' debt.

Overall, we document that the effect of CDS trading on primary loan market allocation is particularly strong if (i) the loan is large, (ii) the lead arranger actively ${ }^{14}$ We are grateful to Amir Sufi for providing this data. See Roberts and Sufi (2009) and Sufi et al. (2009) for a detailed description of the data collection process. 
uses CDS, (iii) the CDS market is liquid, and (iv) the lead arranger reputation is high. Further, (v) borrowers are not more likely to violate loan covenants once CDS are actively traded on the borrowers' debt. This evidence suggests that banks rely less on loan syndication if CDS are available, because tailor-made CDS are a more flexible risk management tool.

\section{Conclusion}

This study provides empirical evidence on how credit derivative trading affects loan syndication. Using CDS trading data and a large sample of syndicated loans, we show that lenders sell significantly lower fractions of loans and are less likely to syndicate loans once credit protection via CDS is possible. These results are robust to controlling for the potential endogeneity of CDS introduction. The effect of CDS trading on

primary loan market allocation is stronger if (i) the loan is larger, (ii) CDS liquidity is higher, and (iii) the lead arranger actively uses CDS contracts.

We further show that (iv) the CDS effect does not vary across borrowers who require different monitoring intensities and that the effect (v) is particularly strong if the lead arranger reputation is high. Further, (vi) borrowers are not more likely to violate loan covenants once CDS are actively traded on the borrowers' debt. If anything, the likelihood of a covenant violation decreases after CDS inception. These results are unsupportive of the conjecture that lenders can no longer credibly commit to monitor a borrower if laying off credit risk anonymously via CDS is possible (Parlour and Winton (2013)).

This study helps to understand the impact of CDS trading on the nature and 
operation of credit markets. Though the importance of credit derivatives has grown enormously in recent years, these effects are not yet fully understood. We provide evidence, which is consistent with CDS being a flexible risk management tool for banks. 


\section{References}

Ashcraft, A. B. and J. A. C. Santos (2009). Has the CDS market lowered the cost of corporate debt? Journal of Monetary Economics 56(4), 514-523.

Cebenoyan, A. S. and P. E. Strahan (2004). Risk management, capital structure and lending at banks. Journal of Banking E Finance 28(1), 19-43.

Chava, S., R. Ganduri, and C. Ornthanalai (2012). Are credit ratings still relevant? Working Paper.

Chava, S. and M. R. Roberts (2008). How does financing impact investment? The role of debt covenants. Journal of Finance 63(5), 2085 - 2121.

Crosbie, P. J. and J. R. Bohn (2003). Modeling Default Risk. KMV LLC.

Das, S., M. Kalimipalli, and S. Nayak (2014). Did CDS trading improve the market for corporate bonds? Journal of Financial Economics 111(2), 495-525.

Dennis, S. A. and D. J. Mullineaux (2000). Syndicated loans. Journal of Financial Intermediation 9(4), 404-426.

Diamond, D. W. (1984). Financial intermediation and delegated monitoring. Review of Economic Studies 51(3), 393-414.

Drucker, S. and M. Puri (2009). On loan sales, loan contracting, and lending relationships. Review of Financial Studies 22(7), 2835-2872.

Duffee, G. R. and C. Zhou (2001). Credit derivatives in banking: Useful tools for managing risk? Journal of Monetary Economics 48(1), 25-54. 
Froot, K. A., D. S. Scharfstein, and J. C. Stein (1993). Risk management: Coordinating corporate investment and financing policies. The Journal of Finance 48(5), 16291658.

Froot, K. A. and J. C. Stein (1998). Risk management: Capital budgeting, and capital structure policy for financial institutions: An integrated approach. Journal of Financial Economics 47(1), 55-82.

Goderis, B., I. W. Marsh, J. V. Castello, and W. Wagner (2007). Bank behaviour with access to credit risk transfer markets. Working Paper.

Goldstein, M. A. and E. S. Hotchkiss (2007). Dealer behavior and the trading of newly issued corporate bonds. Working Paper.

Gorton, G. B. and G. G. Pennachi (1995). Banks and loan sales: Marketing nonmarketable assets. Journal of Monetary Economics 35(3), 389-411.

Hirtle, B. (2009). Credit derivatives and bank credit supply. Journal of Financial Intermediation 18(2), 125-150.

Holmstrom, B. (1979). Moral hazard and observability. Bell Journal of Economics 10(1), 74-91.

Holmstrom, B. and J. Tirole (1997). Financial intermediation, loanable funds, and the real sector. Quarterly Journal of Economics 112(3), 663-691.

Ivashina, V. (2009). Asymmetric information effects on loan spreads. Journal of Financial Economics 92(2), 300-319.

Ivashina, V. and Z. Sun (2011). Institutional stock trading on loan market information. Journal of Financial Economics 100(2), 284-303. 
Merton, R. C. (1974). On the pricing of corporate debt: The risk structure of interest rates. Journal of Finance 29(2), 449-470.

Minton, B. A., R. Stulz, and R. Williamson (2008). How much do banks use credit derivatives to hedge loans? Journal of Financial Services Research 35(1), 1-31.

Parlour, C. A. and A. Winton (2013). Laying off credit risk: Loan sales versus credit default swaps. Journal of Financial Economics 107(1), 25-45.

Roberts, M. R. and A. Sufi (2009). Control rights and capital structure: An empirical investigation. Journal of Finance 64(4), 1657-1695.

Ross, D. G. (2010). The "dominant bank effect:" How high lender reputation affects the information content and terms of bank loans. Review of Financial Studies 23(7), $2730-2756$.

Saretto, A. and H. Tookes (2013). Corporate leverage, debt maturity and credit supply: The role of credit default swaps. Review of Financial Studies 26 (5), 1190-1247.

Shan, S. C., D. Y. Tang, and H. Yan (2014). Credit default swaps and bank risk taking. Working Paper.

Subrahmanyam, M. G., D. Y. Tang, and S. Q. Wang (2014). Does the tail wag the dog? The effect of credit default swaps on credit risk. Review of Financial Studies 27(10), $2927-2960$.

Sufi, A. (2007). Information asymmetry and financing arrangements: Evidence from syndicated loans. The Journal of Finance 62(2), 629-668.

Sufi, A., G. Nini, and D. Smith (2009). Creditor control rights and firm investment policy. Journal of Financial Economics 92(3), 400-420. 
Yasuda, A. (2005). Do bank relationships affect the firms underwriter choice in the corporate-bond underwriting market? Journal of Finance 60(3), 1259-1292. 
Figure 1: CDS Introduction and Loan Share Retained by Lead Arranger

This figure shows the average (median) loan share retained by the lead arranger before and after CDS are actively traded on the borrowers' debt $([-2,+2]$ years surrounding the CDS introduction). Further reported is a control group, i.e., lead shares in loans to borrowers who never have actively traded CDS on their debt but who are otherwise similar to the treated group. Loans are matched based on the observable loan and borrower characteristics reported in Table 1.

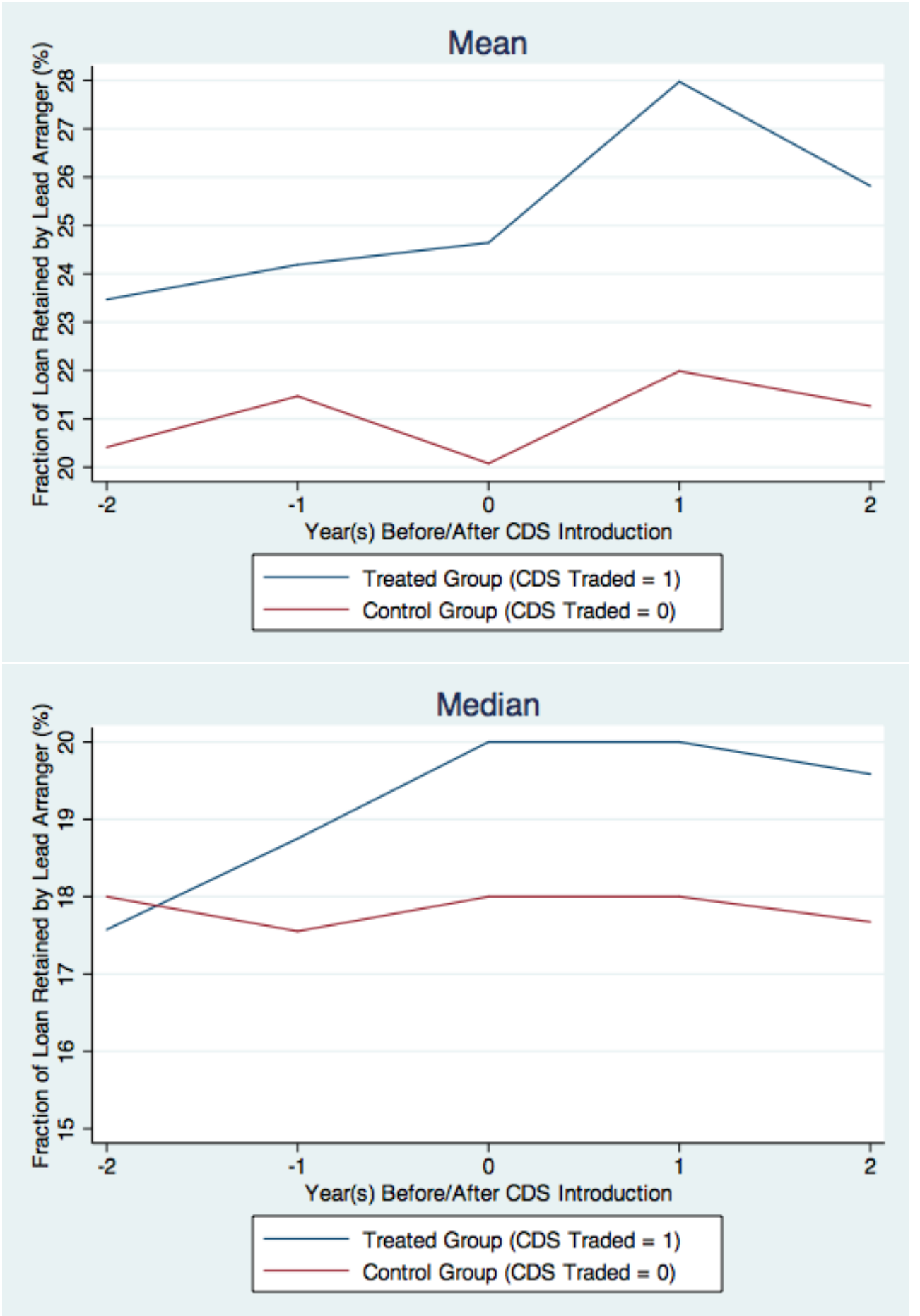


Table 1: Descriptive Statistics: Firms With vs Firms Without Actively Traded CDS Contracts

This table reports summary statistics for CDS trading indicators, the loan share retained by the lead arranger, loan characteristics, and borrower characteristics. CDS Traded indicates whether the firm has actively traded CDS on its debt at any point in time during the sample period. All variables are defined in the Appendix.

\begin{tabular}{|c|c|c|c|c|c|c|c|c|}
\hline & \multicolumn{4}{|c|}{ CDS Traded $=0$} & \multicolumn{4}{|c|}{ CDS Traded $=1$} \\
\hline & Mean & Median & Std & Observations & Mean & Median & Std & Observations \\
\hline \multicolumn{9}{|c|}{ Panel A: CDS Trading Indicators } \\
\hline CDS Trading $(0 / 1)$ & 0.000 & 0.000 & 0.000 & 15,406 & 0.513 & 1.000 & 0.500 & 5,716 \\
\hline \multicolumn{9}{|l|}{ Panel B: Loan Characteristics } \\
\hline Lead Share (\%) & 62.388 & 59.100 & 35.659 & 6,195 & 32.807 & 23.125 & 24.734 & 2,104 \\
\hline Sole Lender (0/1) & 0.158 & 0.000 & 0.365 & 15,406 & 0.015 & 0.000 & 0.122 & 5,716 \\
\hline Facility Amount (million USD) & 240.980 & 125.000 & 396.974 & 15,406 & $1,140.689$ & 600.000 & $2,114.723$ & 5,716 \\
\hline Maturity (Months) & 47.355 & 50.000 & 22.967 & 15,406 & 39.435 & 36.000 & 23.750 & 5,716 \\
\hline All In Spread Drawn (bps) & 240.736 & 225.000 & 158.040 & 15,406 & 124.181 & 75.000 & 124.460 & 5,716 \\
\hline Secured $(0 / 1)$ & 0.621 & 1.000 & 0.485 & 15,406 & 0.217 & 0.000 & 0.412 & 5,716 \\
\hline Performance Pricing $(0 / 1)$ & 0.494 & 0.000 & 0.500 & 15,406 & 0.529 & 1.000 & 0.499 & 5,716 \\
\hline \# Financial Covenants & 1.795 & 2.000 & 1.502 & 15,406 & 1.045 & 1.000 & 1.109 & 5,716 \\
\hline \multicolumn{9}{|c|}{ Panel C: Borrower Characteristics } \\
\hline Total Assets (million USD) & $2,070.527$ & 779.091 & $5,615.610$ & 15,406 & $17,700.643$ & $10,241.409$ & $21,084.003$ & 5,716 \\
\hline Leverage & 0.306 & 0.274 & 0.254 & 15,406 & 0.320 & 0.291 & 0.177 & 5,716 \\
\hline Coverage & 18.603 & 5.196 & 52.186 & 15,406 & 10.221 & 6.154 & 15.394 & 5,716 \\
\hline Profitability & 0.137 & 0.127 & 0.206 & 15,406 & 0.205 & 0.174 & 0.141 & 5,716 \\
\hline Tangibility & 0.330 & 0.263 & 0.247 & 15,406 & 0.400 & 0.384 & 0.225 & 5,716 \\
\hline Current Ratio & 1.840 & 1.571 & 1.187 & 15,406 & 1.330 & 1.213 & 0.609 & 5,716 \\
\hline Market-To-Book & 1.656 & 1.363 & 0.976 & 15,406 & 1.664 & 1.404 & 0.812 & 5,716 \\
\hline Investment Grade $(0 / 1)$ & 0.147 & 0.000 & 0.354 & 15,406 & 0.749 & 1.000 & 0.433 & 5,716 \\
\hline Not Rated $(0 / 1)$ & 0.546 & 1.000 & 0.498 & 15,406 & 0.027 & 0.000 & 0.162 & 5,716 \\
\hline
\end{tabular}


Table 2: CDS Trading, Syndication Propensity, and Lead Share

This table reports difference-in-differences OLS regression results analyzing the impact of CDS trading on syndication propensity and the loan share retained by the lead arranger. Sole Lender (0/1) is a dummy variable, which equals one for single lender loans and zero for syndicated loans Lead Share (\%) is the percentage of the loan held by the lead arranger. CDS Trading (0/1) is a dummy variable, which equals one if CDS are actively traded on the borrower's debt at the time of the loan origination, and zero otherwise. Fixed effects for borrower x lender, year, borrower credit rating, loan purpose, and loan type are included when indicated. All variables are defined in the Appendix. Standard errors are heteroskedasticity robust and clustered at the firm level to account for non-independent observations within firms. *,***** Indicate statistical significance at the $10 \%, 5 \%, 1 \%$ level.

(1)

Sole Lender (0/1)

\begin{tabular}{|c|c|c|}
\hline & Sole Lender $(0 / 1)$ & Lead Share (\%) \\
\hline \multirow[t]{2}{*}{ CDS Trading (0/1) } & $0.029^{* * *}$ & $5.480^{* *}$ \\
\hline & $(0.008)$ & $(2.262)$ \\
\hline \multirow{2}{*}{$\ln$ (Facility Amount) } & $-0.012^{* * *}$ & $-1.830^{* * *}$ \\
\hline & $(0.002)$ & $(0.520)$ \\
\hline \multirow{2}{*}{$\ln$ (Maturity) } & $-0.018^{* * *}$ & $-4.618^{* * *}$ \\
\hline & $(0.004)$ & $(0.803)$ \\
\hline \multirow[t]{2}{*}{ Secured $(0 / 1)$} & 0.001 & -1.159 \\
\hline & $(0.007)$ & $(1.619)$ \\
\hline \multirow[t]{2}{*}{ Performance-Pricing $(0 / 1)$} & $-0.012^{* *}$ & $-8.519^{* * *}$ \\
\hline & $(0.006)$ & $(1.539)$ \\
\hline \multirow{2}{*}{$\ln$ (\# Financial Covenants) } & $-0.013^{*}$ & $-3.791^{* *}$ \\
\hline & $(0.006)$ & $(1.769)$ \\
\hline \multirow[t]{2}{*}{$\ln$ (Total Assets) } & $-0.031^{* * *}$ & $-4.649^{* * *}$ \\
\hline & $(0.010)$ & $(1.687)$ \\
\hline \multirow[t]{2}{*}{ Leverage } & -0.030 & -0.755 \\
\hline & $(0.027)$ & $(2.381)$ \\
\hline \multirow{2}{*}{ Coverage } & -0.000 & 0.017 \\
\hline & $(0.000)$ & $(0.014)$ \\
\hline \multirow[t]{2}{*}{ Profitability } & -0.002 & 5.902 \\
\hline & $(0.027)$ & $(4.307)$ \\
\hline \multirow[t]{2}{*}{ Tangibility } & -0.009 & 9.091 \\
\hline & $(0.043)$ & $(10.757)$ \\
\hline \multirow[t]{2}{*}{ Current Ratio } & $0.009^{*}$ & $2.655^{* * *}$ \\
\hline & $(0.005)$ & $(0.878)$ \\
\hline \multirow{2}{*}{ Market-To-Book } & -0.004 & $-2.532^{* *}$ \\
\hline & $(0.005)$ & $(1.058)$ \\
\hline \multirow[t]{2}{*}{ Intercept } & $0.674^{* * *}$ & $150.580^{* * *}$ \\
\hline & $(0.091)$ & $(15.975)$ \\
\hline Observations & 21,122 & 8,299 \\
\hline Adj. $R^{2}$ & 0.027 & 0.139 \\
\hline Borrower x Lender Fixed Effects & Yes & Yes \\
\hline Time Fixed Effects & Yes & Yes \\
\hline Credit Rating Fixed Effects & Yes & Yes \\
\hline Loan Purpose Fixed Effects & Yes & Yes \\
\hline Loan Type Fixed Effects & Yes & Yes \\
\hline
\end{tabular}




\section{Table 3: CDS Trading and Primary Loan Market Allocation - IV Estimation}

This table reports instrumental variable regression results analyzing the impact of CDS trading on primary loan market allocation. The instrument for CDS trading, Lender FX Usage, is the average amount of foreign exchange derivatives held by all lead arrangers that lend money to the borrower in the previous five years as a fraction of the total assets of the lead arrangers. A probit model is used to obtain the probability of CDS trading for each firm-year (column 1). The predicted probability is used as the instrumental variable in the models reported in column 2 and column 3 . The dependent variable in the first stage, CDS Trading (0/1), is a dummy variable which equals one if CDS are actively traded on the firm's debt and zero otherwise. Sole Lender (0/1) is a dummy variable, which equals one for single lender loans and zero for syndicated loans. Lead Share (\%) is the percentage of the loan held by the lead arranger. Fixed effects for borrower x lender, year, industry, borrower credit rating, loan purpose, and loan type, as well as other loan and borrower characteristics are included when indicated. All variables are defined in the Appendix. Standard errors are heteroskedasticity robust and clustered at the firm level to account for non-independent observations within firms. *,**,*** Indicate statistical significance at the $10 \%, 5 \%, 1 \%$ level.

(1)

CDS Trading $(0 / 1)$

\begin{tabular}{|c|c|c|c|}
\hline Lender FX Usage & $\begin{array}{c}3.229^{* *} \\
(1.381)\end{array}$ & & \\
\hline Instrumented CDS Trading & & $\begin{array}{r}-0.083^{* * *} \\
(0.026)\end{array}$ & $\begin{array}{r}-19.494^{* * *} \\
(5.584)\end{array}$ \\
\hline Intercept & $\begin{array}{r}-4.248^{* * *} \\
(0.651)\end{array}$ & $\begin{array}{r}0.565^{* * *} \\
(0.089)\end{array}$ & $\begin{array}{r}104.313^{* * *} \\
(21.141)\end{array}$ \\
\hline Observations & 39,513 & 18,480 & 6,877 \\
\hline Adj. $R^{2}$ & & 0.0236 & 0.144 \\
\hline Pseudo $R^{2}$ & 0.482 & & \\
\hline First-Stage F-Statistic & $1471.44^{* * *}$ & & \\
\hline Borrower Characteristics & Yes & Yes & Yes \\
\hline Loan Characteristics & No & Yes & Yes \\
\hline Borrower x Lender Fixed Effects & No & Yes & Yes \\
\hline Time Fixed Effects & Yes & Yes & Yes \\
\hline Industry Fixed Effects & Yes & No & No \\
\hline Credit Rating Fixed Effects & Yes & Yes & Yes \\
\hline Loan Purpose Fixed Effects & No & Yes & Yes \\
\hline Loan Type Fixed Effects & No & Yes & Yes \\
\hline
\end{tabular}


Table 4: CDS Trading and Syndication Propensity: The Impact of Loan Size, CDS Liquidity, and Bank CDS Holdings

This table reports difference-in-differences OLS regression results analyzing how the impact of CDS trading on syndication propensity varies with bank CDS holdings (Panel A), loan size (Panel B), and CDS market liquidity (Panel C). Sole Lender (0/1) is a dummy variable, which equals one for single lender loans and zero for syndicated loans. CDS Trading (0/1) is a dummy variable, which equals one if CDS are actively traded on the borrower's debt at the time of the loan origination, and zero otherwise. In (Facility Amount) is the log of facility volume (\$ million). Low Liquidity (0/1)/Medium Liquidity (0/1)/High Liquidity (0/1) is a dummy variable which equals one if the borrower's CDS bid-ask spread is in the low/medium/high quantile in the month prior to the loan issue, and zero otherwise. $C D S$ Bank (0/1) is a dummy variable, which equals one if the lead lender ever reports a positive notional CDS amount (purchased protection) in the 2000 to 2010 period, and zero otherwise. $\ln$ (Bank CDS Holding) is the log of notional CDS $\$$ amount (purchased protection) that the lead lender reports in the quarter prior to the loan issue. Fixed effects for borrower x lender, year, borrower credit rating, loan purpose, and loan type, as well as other loan and borrower characteristics are included when indicated. All variables are defined in the Appendix. Standard errors are heteroskedasticity robust and clustered at the firm level to account for non-independent observations within firms. $* * *, * * *$ Indicate statistical significance at the $10 \%, 5 \%, 1 \%$ level.

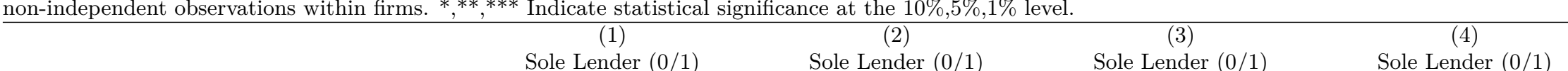

Panel A: Bank CDS Holdings

CDS Trading $(0 / 1) *$ CDS Bank $(0 / 1)$

$0.122^{* *}$

CDS Trading $(0 / 1) * \ln ($ Bank CDS Holding)

(0.060)

$\ln ($ Bank CDS Holding)

$0.029^{* * *}$

$(0.011)$

$-0.014^{*}$

$(0.008)$

\section{Panel B: Loan Size}

CDS Trading $(0 / 1) * \ln ($ Facility Amount)

$\ln$ (Facility Amount)

\section{Panel C: CDS Liquidity}

CDS Trading $(0 / 1) *$ Low Liquidity $(0 / 1)$

CDS Trading $(0 / 1) *$ Medium Liquidity $(0 / 1)$

CDS Trading $(0 / 1) *$ High Liquidity $(0 / 1)$

CDS Trading (0/1)

Intercept

(0.060)

$0.566^{* * *}$

$(0.099)$

Sole Lender $(0 / 1)$

Sole Lender $(0 / 1)$

\begin{tabular}{lccc} 
& $(0.099)$ & $(0.350)$ & $(0.093)$ \\
\hline Observations & 14,326 & 4,744 & 21,122 \\
Adj. $R^{2}$ & 0.034 & 0.066 & 0.027 \\
Borrower Characteristics & Yes & Yes & Yes \\
Loan Characteristics & Yes & Yes & Yes \\
Borrower x Lender Fixed Effects & & Yes & Yes \\
Time Fixed Effects & Yes & Yes & Yes \\
Credit Rating Fixed Effects & Yes & Yes & Yes \\
Loan Purpose Fixed Effects & Yes & Yes & Yes \\
Loan Type Fixed Effects & Yes & Yes & Yes \\
\hline \hline
\end{tabular}

$0.009^{*}$

$(0.005)$

$-0.014^{* * *}$

(0.002)

$\begin{array}{lcc} & & 0.015^{* *} \\ & & (0.007) \\ & & 0.024^{* * *} \\ & (0.008) \\ & & 0.026^{* *} \\ & & (0.011) \\ -0.548^{* *} & & \\ (0.226) & -0.154 & \\ 0.644^{*} & (0.109) & 0.671^{* * *} \\ (0.350) & 0.698^{* * *} & (0.091) \\ 4,744 & (0.093) & 21,122 \\ 0.066 & 21,122 & 0.026 \\ & 0.027 & \text { Yes } \\ \text { Yes } & & \text { Yes } \\ \text { Yes } & \text { Yes } & \text { Yes } \\ \text { Yes } & \text { Yes } & \text { Yes } \\ \text { Yes } & \text { Yes } & \text { Yes } \\ \text { Yes } & \text { Yes } & \text { Yes } \\ \text { Yes } & \text { Yes } & \text { Yes } \\ \text { Yes } & \text { Yes } & \end{array}$


Table 5: Risk Management vs Moral Hazard: Cross-Borrower Variation in Monitoring Intensity and Opacity

This table reports difference-in-differences OLS regression results analyzing how the impact of CDS trading on primary loan market allocation varies with borrower risk and borrower opacity. Sole Lender $(0 / 1)$ is a dummy variable, which equals one for single lender loans and zero for syndicated loans. CDS Trading ( $0 / 1)$ is a dummy variable, which equals one if CDS are actively traded on the borrower's debt at the time of the loan origination, and zero otherwise. \# Analysts is the number of analysts covering the borrower at the time of the loan origination. Tangibility is defined as net property plant and equipment divided by total assets. Sub-Investment Grade (0/1) is a dummy variable that equals one if the borrower is rated BB+ or worse at the time of the loan issue, and zero otherwise. Distance-To-Default is the borrower's distance-to-default at the time of the loan issue. Altman Z is the borrower's Altman Z-Score at the time of the loan issue. Fixed effects for borrower x lender, year, borrower credit rating, loan purpose, and loan type, as well as other loan and borrower characteristics are included when indicated. All variables are defined in the Appendix. Standard errors are heteroskedasticity robust and clustered at the firm level to account for non-independent observations within firms. $*, * *, * * *$ Indicate statistical significance at the $10 \%, 5 \%, 1 \%$ level.

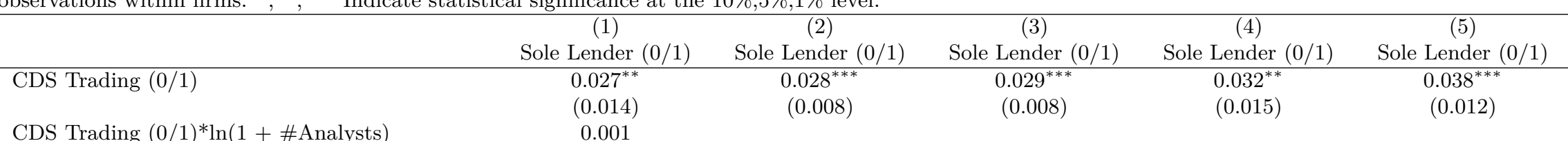

CDS Trading $(0 / 1) * \ln (1+$ \#Analysts $)$

0.001

$(0.008)$

(0.008)

$(0.015)$

$(0.012)$

CDS Trading (0/1)*Tangibility

0.001

CDS Trading (0/1)*Sub-Investment Grade (0/1)

$(0.027)$

CDS Trading $(0 / 1)^{*}$ Distance-To-Default

$(0.015)$

CDS Trading $(0 / 1)^{*}$ Altman Z

$\ln (1+$ \#Analysts $)$

$-0.007^{* * *}$

$(0.002)$

$-0.006$

$-0.009$

$(0.043)$

$(0.044)$

Sub-Investment Grade (0/1)

Distance-To-Default

Altman Z

$(0.043)$

0.008

0.021
$(0.049)$

(0.003)

Intercept $0.662^{* *}$

$(0.090)$

(0.089)

21,122

0.027

0.027

0.023

$-0.000$

(0.003)

Adj. $R^{2}$

Yes

Borrower Characteristics

Loan Characteristics

Yes

Yes

Yes

Yes

Borrower x Lender Fixed Effects

Time Fixed Effects

Yes Yes

Credit Rating Fixed Effects

Loan Purpose Fixed Effects

Loan Type Fixed Effects

$\begin{array}{ll}\text { Yes } & \text { Yes } \\ \text { Yes } & \text { Yes }\end{array}$

Yes Yes

Yes

Yes
Yes

$\begin{array}{cc} & -0.002 \\ 0.705^{* * *} & (0.004) \\ (0.110) & 0.695^{* * *} \\ 17,229 & (0.095) \\ 0.027 & 20,587 \\ & 0.027 \\ \text { Yes } & \text { Yes } \\ \text { Yes } & \text { Yes } \\ & \\ \text { Yes } & \text { Yes } \\ \text { Yes } & \text { Yes } \\ \text { Yes } & \text { Yes } \\ \text { Yes } & \text { Yes } \\ \text { Yes } & \text { Yes }\end{array}$


Table 6: Risk Management vs Moral Hazard: Lead Arranger Reputation

This table reports difference-in-differences OLS regression results analyzing how the impact of CDS trading on primary loan market allocation varies with the reputation of the lead arranger. Sole Lender $(0 / 1)$ is a dummy variable, which equals one for single lender loans and zero for syndicated loans. $C D S$ Trading (0/1) is a dummy variable, which equals one if CDS are actively traded on the borrower's debt at the time of the loan origination, and zero otherwise. Bank Reputation is the market share (by amount) of the lead arranger in the year prior to the loan in question. Big-3 Bank (0/1) is a dummy variable, which equals one if the lead bank is either Citibank, JP Morgan Chase, or Bank of America, and zero otherwise. Big-10 Bank (0/1) is a dummy variable, which equals one if the lead bank is one of the ten most frequent lead arrangers in the loan sample, and zero otherwise. Fixed effects for borrower $\mathrm{x}$ lender, year, borrower credit rating, loan purpose, and loan type, as well as other loan and borrower characteristics are included when indicated. All variables are defined in the Appendix. Standard errors are heteroskedasticity robust and clustered at the firm level to account for non-independent observations within firms. *,**,*** Indicate statistical significance at the 10\%,5\%,1\% level.

\begin{tabular}{lccc}
\hline & $(1)$ & $(2)$ & $(3)$ \\
& Sole Lender $(0 / 1)$ & Sole Lender $(0 / 1)$ & Sole Lender $(0 / 1)$ \\
\hline CDS Trading $(0 / 1)$ & 0.024 & 0.014 & -0.002 \\
& $(0.018)$ & $(0.017)$ & $(0.017)$ \\
CDS Trading $(0 / 1)^{*}$ Bank Reputation & 0.049 & & \\
CDS Trading $(0 / 1)^{*}$ Big-3 Bank (0/1) & $(0.128)$ & 0.019 & \\
& & $(0.017)$ & $0.037^{* *}$ \\
CDS Trading $(0 / 1)^{*}$ Big-10 Bank (0/1) & & & $(0.017)$ \\
Bank Reputation & -0.028 & & \\
& $(0.061)$ & $0.672^{* * *}$ & $0.668^{* * *}$ \\
Intercept & $0.622^{* * *}$ & $(0.091)$ & $(0.091)$ \\
\hline Observations & $(0.084)$ & 21,122 & 21,122 \\
Adj. $R^{2}$ & 20,551 & 0.027 & 0.027 \\
Borrower Characteristics & 0.025 & & \\
Loan Characteristics & & Yes & Yes \\
Borrower x Lender Fixed Effects & Yes & Yes & Yes \\
Time Fixed Effects & Yes & Yes & Yes \\
Credit Rating Fixed Effects & Yes & Yes & Yes \\
Loan Purpose Fixed Effects & Yes & Yes & Yes \\
Loan Type Fixed Effects & Yes & Yes & Yes \\
\hline \hline
\end{tabular}


Table 7: Risk Management vs Moral Hazard: Loan Outcomes

This table reports difference-in-differences OLS regression results analyzing the impact of CDS trading on covenant violations. Column 1 presents firm-level evidence. Columns 2-3 present loan-level evidence. CDS Trading (0/1) is a dummy variable, which equals one if CDS are actively traded on the firm's debt in quarter $t$ (column 1) or at the time of loan origination (columns 2-3), and zero otherwise. Covenant Violation (0/1) is a dummy variable, which equals one if the firm violated a covenant in quarter $t$, and zero otherwise. Covenant Violation $(t+k)(0 / 1)$ is a dummy variable, which equals one if the firm violated a covenant in the $k$ quarters following the loan origination, and zero otherwise. Fixed effects for borrower $\mathrm{x}$ lender, firm, year, borrower credit rating, loan purpose, and loan type, as well as other loan and borrower characteristics are included when indicated. All variables are defined in the Appendix. Standard errors are heteroskedasticity robust and clustered at the firm level to account for non-independent observations within firms. *,**,*** Indicate statistical significance at the $10 \%, 5 \%, 1 \%$ level.

Firm-Level

\begin{tabular}{ccc} 
Firm-Level & \multicolumn{2}{c}{ Loan-Level } \\
\cline { 4 - 4 } \cline { 3 - 3 } Covenant Violation $(0 / 1)$ & $(2)$ & $(3)$ \\
\hline$-0.011^{*}$ & Covenant Violation $(\mathrm{t}+4)(0 / 1)$ & -0.031 \\
$(0.006)$ & 0.032 & -0.001 \\
& $(0.048)$ & $(0.001)$ \\
& 0.000 & 0.459 \\
0.012 & $(0.000)$ & $(0.548)$ \\
$(0.037)$ & 0.137 & 3,175 \\
69,538 & $(0.354)$ & 0.079 \\
0.010 & 4,289 & Yes \\
Yes & 0.079 & Yes \\
No & Yes & No \\
Yes & Yes & Yes \\
No & No & Yes \\
Yes & Yes & Yes \\
Yes & Yes & Yes \\
No & Yes & Yes \\
No & Yes &
\end{tabular}




\section{Appendix A}

\begin{tabular}{|c|c|c|}
\hline Variable Name & Definition & Source \\
\hline \multicolumn{3}{|c|}{ CDS Trading Indicators: } \\
\hline CDS Trading $(0 / 1)$ & $\begin{array}{l}\text { A dummy variable, which equals one if CDS are actively traded on the borrower's debt at the time } \\
\text { of the loan origination, and zero otherwise. }\end{array}$ & Bloomberg \& CMA \\
\hline CDS Traded $(0 / 1)$ & $\begin{array}{l}\text { A dummy variable, which equals one if CDS are traded on the borrower's debt at any point of time } \\
\text { during the sample period, and zero otherwise. }\end{array}$ & Bloomberg \& CMA \\
\hline Low Liquidity $(0 / 1)$ & $\begin{array}{l}\text { A dummy variable, which equals one if the borrower's CDS bid-ask spread is in the high quantile } \\
\text { in the month prior to the loan issue, and zero otherwise. }\end{array}$ & Bloomberg \\
\hline Medium Liquidity (0/1) & $\begin{array}{l}\text { A dummy variable, which equals one if the borrower's CDS bid-ask spread is in the medium quantile } \\
\text { in the month prior to the loan issue, and zero otherwise. }\end{array}$ & Bloomberg \\
\hline High Liquidity $(0 / 1)$ & $\begin{array}{l}\text { A dummy variable, which equals one if the borrower's CDS bid-ask spread is in the low quantile in } \\
\text { the month prior to the loan issue, and zero otherwise. }\end{array}$ & Bloomberg \\
\hline \multicolumn{3}{|l|}{ Loan Characteristics: } \\
\hline Sole Lender $(0 / 1)$ & A dummy variable, which equals one for single lender loans and zero for syndicated loans. & Dealscan \\
\hline Lead Share $(\%)$ & The share of the loan retained by the lead arranger in $\%$. & Dealscan \\
\hline Facility Amount & Overall facility volume in \$million. & Dealscan \\
\hline
\end{tabular}




\section{- continued from previous page}

\begin{tabular}{|c|c|c|}
\hline Variable Name & Definition & Source \\
\hline Maturity & Time to maturity in months. & Dealscan \\
\hline Secured $(0 / 1)$ & A dummy variable, which equals one if the loan is secured, and zero otherwise. & Dealscan \\
\hline All In Spread Drawn & The facility All In Spread Drawn (bps). & Dealscan \\
\hline Performance Pricing $(0 / 1)$ & $\begin{array}{l}\text { A dummy variable, which equals one if the loan contains a performance pricing provision, and zero } \\
\text { otherwise. }\end{array}$ & Dealscan \\
\hline $\begin{array}{l}\text { \# Financial Covenants } \\
\text { Lender Characteristics: }\end{array}$ & The number of financial covenants in the loan contract. & Dealscan \\
\hline CDS Bank $(0 / 1)$ & $\begin{array}{l}\text { A dummy variable, which equals one if the lead lender ever reports a positive notional CDS amount } \\
\text { (purchased protection) in the } 2000 \text { to } 2010 \text { period, and zero otherwise. }\end{array}$ & Call Reports \\
\hline Bank CDS Holdings & $\begin{array}{l}\text { The notional CDS amount (\$million) that the lead lender reports in the quarter prior to the loan } \\
\text { issue. }\end{array}$ & Call Reports \\
\hline Lender FX Usage & $\begin{array}{l}\text { The average amount of foreign exchange derivatives held by all the lead arrangers that lend money } \\
\text { to the company in the previous five years as a fraction of the total loans of the lead arrangers. }\end{array}$ & Call Reports \\
\hline Bank Reputation & The market share (by amount) of the lead arranger in the year prior to the loan in question. & Dealscan \\
\hline Big-3 Bank (0/1) & $\begin{array}{l}\text { A dummy variable, which equals one if the lead bank is either Citibank, JP Morgan Chase, or Bank } \\
\text { of America, and zero otherwise. }\end{array}$ & Dealscan \\
\hline
\end{tabular}




\section{- continued from previous page}

\section{Variable Name}

Big-10 Bank (0/1)

A dummy variable, which equals one if the lead bank is among the ten most active lead arrangers Dealscan in the US syndicated loan market, and zero otherwise.

\section{Borrower Characteristics:}

Total Assets

Leverage

Market-to-Book

Tangibility
Firm's total assets in \$million.

Long-term debt divided by total assets.

Market value of the firm divided by the book value of assets.

Net property plant and equipment divided by total assets.

Interest expenses divided by EBITDA.

EBITDA divided by total assets.

Current assets divided by current liabilities.

A dummy variable, which equals one if the borrower was not rated by $\mathrm{S} \& \mathrm{P}$ at the time of the debt issue.

Investment Grade (0/1)
A dummy variable, which equals one if the borrower was rated BBB- or better by S\&P at the time of the debt issue.
Compustat

Compustat

Compustat

Compustat

Compustat

Compustat

Compustat

Compustat

Compustat

Sub-Investment Grade (0/1) A dummy variable, which equals one if the borrower was rated BB+ or worse by S\&P at the time Compustat of the debt issue. 


\section{- continued from previous page}

\section{Variable Name}

\# Analysts

Distance-To-Default

\section{Definition}

Source

The number of analysts covering the borrower at the time of the loan origination.

$\mathrm{I} / \mathrm{B} / \mathrm{E} / \mathrm{S}$

A market-based measure of default risk based on KMV/Merton methodology as described in Crosbie and Bohn (2003):

Own Calculation

CRSP, Compustat

where:

$V_{A}=$ market value of assets

$D=$ debt, defined as the debt in current liabilities plus one-half long-term debt

$\sigma_{A}=$ one-year asset volatility

$V_{A}$ and $\sigma_{A}$ are unobservable, but are approximated by using the market value of equity $\left(V_{E}\right)$, the one-year equity volatility $\left(\sigma_{E}\right)$, the three-month treasury bill rate $(r)$, and debt $(D)$ and solving Merton (1974) model of pricing a firm's debt and equity for a one-year time horizon $(T=1)$ :

$V_{E}=V_{A} * N\left(d_{1}\right)-e^{-r t} * D * N\left(d_{2}\right)$

$\sigma_{E}=\left(V_{A} / V_{E}\right) * N\left(d_{1}\right) * \sigma_{A}$

where:

$d_{1}=\left[\ln \left(V_{A} / D\right)+\left(r+0.5 * \sigma_{A}^{2}\right) * T\right] /\left[\sigma_{A} * \sqrt{T}\right]$

$d_{2}=d_{1}-\sigma_{A} * \sqrt{T}$ 
- continued from previous page

Variable Name

\section{Definition}

Altman Z

Covenant Violation $(0 / 1)$
$N()=$ the cumulative normal distribution

Altman Z-Score defined as 1.2 (Working Capital/Total Assets) + 1.4 (Retained Earnings/Total As-

sets $)+3.3($ EBIT/Total Assets $)+0.6($ Market Value of Equity/Book Value of Debt) + (Sales/Total

Assets)

Source

Compustat

A dummy variable, which equals one if the firm violated a covenant in the respective quarter, and

Sufi et al. (2009) zero otherwise. 
4 


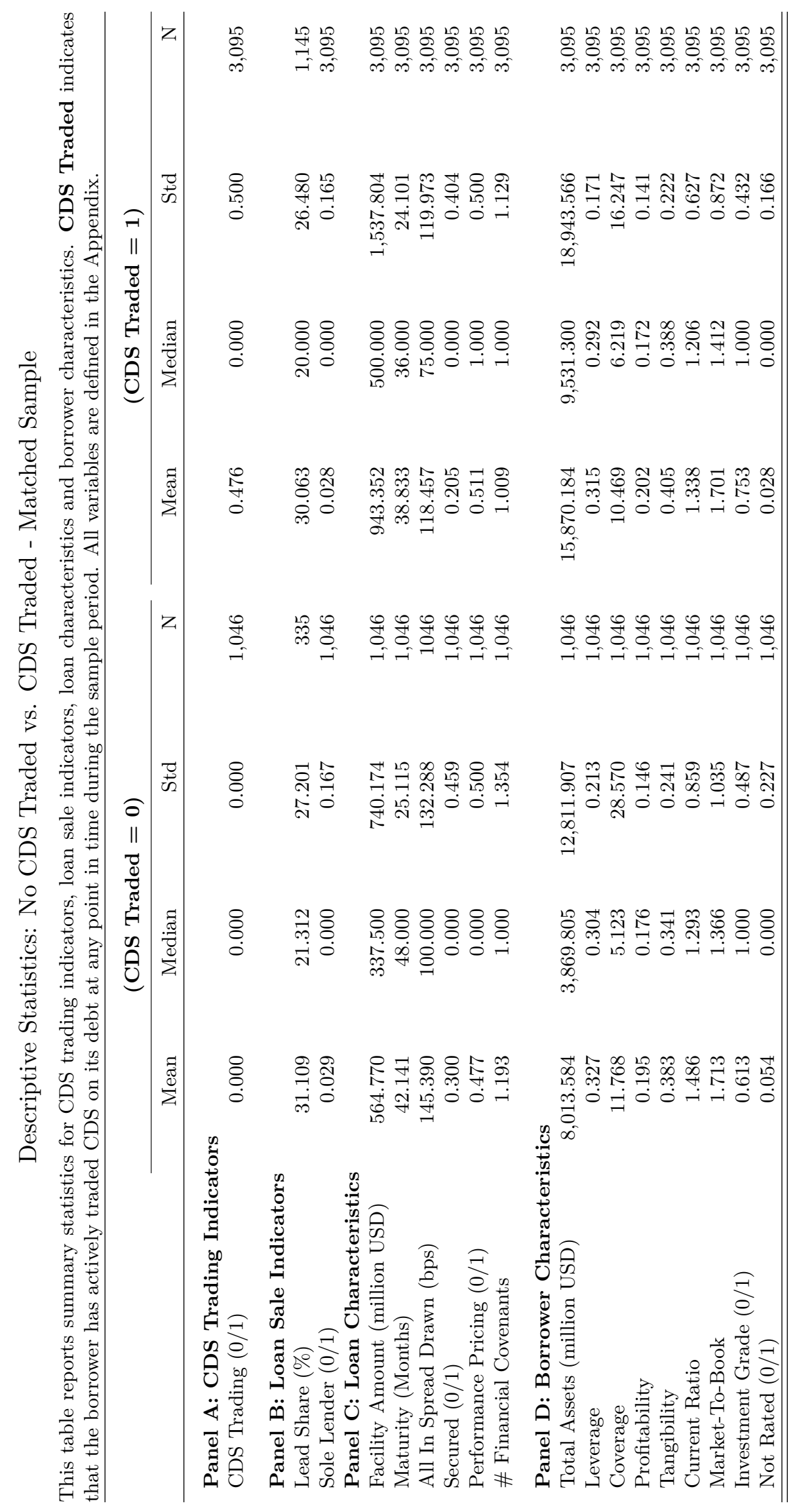

